Revista Água Viva

\title{
A JORNADA DO HERÓI EM A GUERRA DOS TRONOS: EDDARD STARK, UM HERÓI DESCONSTRUÍDO
}

\author{
THE HERO'S JOURNEY IN THE THRONE WAR: EDDARD STARK, A \\ DECEIVED HERO
}

Pedro Afonso Barth ${ }^{1}$

RESUMO: O presente artigo aproxima a jornada do herói, listada na obra As mil faces do herói de Joseph Campbell (2007), com a trajetória percorrida pela personagem Eddard Stark de A guerra dos Tronos (2011), de George R. R. Martin. A trajetória de Eddard Stark como herói não se completa, pois o personagem é brutalmente assassinado. Chegase à conclusão que há um rompimento com o arquétipo do herói, e que a obra de Martin propõe um novo perfil heroico para o leitor de fantasia épica do século XXI.

Palavras-chave: Saga do Herói; Literatura de Massa; Monomito.

ABSTRACT: This article approaches the hero's journey, listed in the book The thousand faces of Hero by Joseph Campbell (2007), with the trajectory of the character Eddard Stark in Game of Thrones (2011), George R. R. Martin. The trajectory of Eddard Stark as a hero is not complete, because the character is brutally murdered. It reaches the conclusion that there is a break with the archetypal hero, and that the work of Martin proposes a new profile for the hero epic fantasy reader of the XXI century.

Keywords: Hero's Saga; Mass Literature; Monomyth.

\section{INTRODUÇÃO}

O fantástico e o mágico fascinam o espírito humano desde o início dos tempos e, mesmo em pleno século XXI tem potencial para conquistar milhares de leitores. Prova disso, é o fato de, hodiernamente, um dos livros mais vendidos no mundo seja Game of Thrones (Guerra dos Tronos) de George R. R. Martin. A obra é o primeiro volume de

\footnotetext{
${ }^{1}$ Doutorando na Universidade Estadual de Maringá (UEM). Mestre em Letras pela Universidade de Passo Fundo (UPF/2016). Professor Colaborador da Universidade Estadual de Maringá. Pesquisador no Grupo do CNPq FORPROLL: Formação de Professores de Línguas e Literatura e aluno pesquisador no grupo CNPq CELLE- Centro de Estudos de Literatura, Leitura e Escrita: História e Ensino. E-mail: pedroabarth@hotmail.com
} 
uma série de fantasia intitulada $A$ song of ice and fire (Crônicas de Gelo e fogo). A história, - ambientada em um ambiente fantástico, retrata reis, rainhas, cavaleiros, dragões e zumbis - une elementos fantásticos, clima medieval e intrigas políticas. O que talvez possa explicar o êxito da obra entre as massas ${ }^{2}$, além do apelo que as obras de fantasia possuem no imaginário coletivo, seja o fato da história lidar com questões atemporais, entre elas, o mito do herói.

O presente estudo pretende analisar como o mito do herói está presente e pode ser percebido em um dos personagens de A Guerra dos tronos (2011). Daremos especial atenção a Joseph Campbell (2007), o introdutor do o conceito de jornada ou saga do herói - Um itinerário que se reproduz em grande parte das narrativas míticas e que representa a essência humana. Eddard Stark é a personagem da obra A Guerra dos Tronos (2011) que mais apresenta aproximações com a saga do herói e tem uma trajetória que tem elementos em comum com os apontados por Vladimir Propp (2001) no livro Morfologia do Conto Maravilhoso. Entretanto, a jornada de Eddard Stark como herói não se completa, pois o personagem é brutalmente assassinado.

O objetivo deste trabalho é elencar as semelhanças e diferenças que a personagem Eddard Stark apresenta em relação à jornada do herói de Joseph Campbell (2007), além de relacionar aspectos dos estudos das funções de personagens de contos maravilhosos de Vladimir Propp (1976; 2001) com a teoria de Campbell (2007) e de Vogler (2006). É preciso considerar que essas teorias foram elaboradas por meio da análise de contos orais e mitos. Sendo assim, os estudos dos autores auxiliam na explicação das similaridades dessas narrativas e não de histórias criadas artificialmente. Já Vogler (2006), por sua vez, discípulo de Campbell (2007), criou um percurso, praticamente um manual, a ser trilhado por escritores e roteiristas, baseado na obra de Campbell O herói das Mil faces. Ou seja, nenhum dos autores propôs-se a analisar a trajetória de um personagem idealizado por um autor que poderia, deliberadamente, romper com a saga do herói. Entretanto, podemos estabelecer, por meio desses autores, a forma que o arquétipo do herói é utilizado em uma obra de fantasia épica do século XXI.

A possibilidade de entender até que ponto a trajetória do herói é utilizada no enredo de Guerra dos tronos (2011) é importante, tanto para compreender como o autor

\footnotetext{
${ }^{2} \mathrm{O}$ livro foi adaptado pela emissora americana $\mathrm{HBO}$ e foi convertido na série de sucesso Game of thrones. O sucesso da série ampliou ainda mais o número de leitores dos livros.
} 
se apropria da imagem do herói clássico para desconstruí-la, como para ajudar a entender o fascínio que a obra gera em milhões de leitores espalhados pelo mundo.

\section{Das funções de Propp à jornada do herói de Campbell: o mito do herói nas narrativas}

A busca por entender a influência que os mitos operam nas narrativas humanas não é recente. Antropólogos e estudiosos de literatura oral pontuam que a maioria das mitologias humanas possui pontos de contato, uma recorrência de figuras, de imagens. Lendas e histórias míticas de grupos humanos distintos tinham uma estrutura muito semelhante. O principal questionamento dos estudiosos era entender se haveria um padrão universal nas narrativas orais. O padrão universal explicaria, por exemplo, porque lendas e histórias, de grupos, tão distantes geograficamente quanto os aborígenes da Austrália e os antigos celtas da Europa, apresentariam estruturas semelhantes.

No início do século XX, o filólogo russo Vladimir Propp (2001; 1976) analisou metodologicamente centenas de narrativas populares russas e procurou apontar quais as características comuns existentes entre elas. O trabalho gerou a obra Morfologia do Conto Maravilhoso, publicada originalmente em 1928 na Rússia, mas que foi traduzida para o inglês apenas em 1958. O autor partiu da premissa que o estudo dos contos precisaria ser objetivo e operar com ferramentas analíticas e classificatórias. Propp (2001) acreditava que o estudo de contos deveria seguir os moldes dos estudos das formas da natureza, sendo absolutamente científico. Para o filólogo, a única maneira de conseguir êxito, seria determinar as conexões constantes existentes nas histórias, - os elementos permanentes -, e não apenas comparar estruturalmente os contos.

O objetivo de Propp (1976; 2001) era descobrir a forma do conto de magia enquanto gênero e encontrar uma razão histórica para a uniformidade. Apesar de contundente, a obra do estudioso russo não teve a preocupação de responder se todas as histórias folclóricas, míticas dos povos humanos tem um mesmo padrão. Seu foco era o conto maravilhoso russo. Entretanto, sua obra é importante no sentido de estabelecer que a maioria das narrativas orais lida com as mesmas figuras, os mesmos personagens. Em outros termos, as narrativas orais manobram um pequeno número de mitos.

Propp (1976) afirma que os elementos constantes, permanentes de um conto maravilhoso, são as funções dos personagens, independente da forma que as executam. As funções seriam as bases constitutivas do conto. O estudo proppiano provou que a 
repetição de funções é surpreendente e, assim, o estudioso russo concluiu que os números de funções nos contos de magia são limitados e a sequência das funções é sempre idêntica. Desta maneira, todos os contos fantásticos são monotípicos quanto à construção. $\mathrm{O}$ autor elenca apenas trinta e uma funções. Para explicar a maneira que as funções se entrelaçam aos personagens, Propp (2001, p. 44) diz que "numerosas funções se agrupam logicamente segundo determinadas esferas. Estas esferas correspondem, grosso modo, aos personagens que realizam as funções. São as esferas da ação." No conto maravilhoso encontramos as seguintes esferas de ação: o antagonista, o falso-herói, o doador, a princesa, o mandante, o auxiliar e o herói.

Apesar de ter executado uma análise estrutural dos contos fantásticos e operar com muito rigor cientifico, Propp (2001, p. 136) reconheceu, décadas depois da publicação de Morfologia do Conto Maravilhoso, algumas limitações do seu estudo

\begin{abstract}
É bem possível que o método de análise das narrativas segundo as funções dos personagens se revele útil também para os gêneros narrativos não só do folclore, mas também da literatura. Todavia, os métodos propostos neste volume antes do aparecimento do estruturalismo, bem como os métodos dos estruturalistas, que almejam o estudo objetivo e exato da literatura, possuem também os seus limites de aplicação. Eles são possíveis e fecundos no caso de uma repetição em ampla escala. É o que ocorre na língua, é o que ocorre no folclore. Mas quando a arte se torna campo de ação de um gênio irrepetível, o uso dos métodos exatos dará resultados positivos somente se o estudo das repetições for acompanhado do estudo daquele algo único para o qual até agora olhamos como a manifestação de um milagre incognoscível. Seja qual for a rubrica sob a qual inscrevamos a Divina Comédia ou as tragédias de Shakespeare, o gênio de Dante e o gênio de Shakespeare não se repetem e sua análise não pode ser reduzida aos métodos exatos. E se, no início deste artigo, colocamos em relevo as afinidades entre as leis estudadas pelas ciências exatas e aquelas das ciências humanas, gostaríamos de concluir lembrando sua diferença fundamental e específica.
\end{abstract}

Apesar de ser fiel aos "métodos exatos" de análise de uma narrativa, Propp reconhece que as histórias criadas artificialmente por "gênios irrepetíveis" não são facilmente enquadradas nas suas trinta e uma funções.

O autor russo qualificou o conto maravilhoso como "mítico" e provou que o mito estaria na gênese do conto maravilhoso. Entretanto, muitos críticos de sua obra especialmente o antropólogo Lèvi Strauss - afirmam que o cientista russo separa a forma do conteúdo, o conto do mito, e assim negligencia o contexto etnográfico, não 
conseguindo perceber o folclore como fenômeno específico. Em sua defesa, Propp (2001, p. 128) argumentou "o fato de ocupar-me do conto maravilhoso deve-se ao meu restrito horizonte científico; caso contrário, eu teria provavelmente experimentado meu método não sobre os contos, mas sobre os mitos". Mesmo analisando apenas os contos, o trabalho de Propp teve importantes contribuições nos estudos dos mitos nas narrativas orais. Vamos agora tratar mais diretamente do que é mito e especialmente do mito do herói.

Não temos a pretensão, nesse curto trabalho, de discutir os diferentes conceitos de mito em toda sua profundidade. Vamos apenas contrapor dois conceitos antagônicos acerca do que é um mito. O primeiro é o entendimento de mito como alegoria de fenômenos da natureza que o homem primitivo buscava compreender. Segundo Pierre Grimal (2009, p. 7) o mito ocupa nas civilizações humanas o papel de ser a narrativa que busca explicar o mundo. Essa seria uma necessidade de todos os seres humanos, já que “todos os povos, em um determinado momento de sua evolução, criaram lendas, ou seja, relatos fabulosos aos quais durante certo tempo deram crédito - ao menos em algum grau".

No segundo conceito, ancorado em Jung (1996), os mitos resultariam da tendência do inconsciente em projetar as suas ocorrências internas, traduzindo-as em imagens. Mitos não seriam apenas uma forma narrativa e sim a condensação de experiências vividas repetidamente durante toda a história da humanidade. Seriam, também, a expressão da linguagem interior, das estruturas mentais individuais que se tornam coletivas. Temas idênticos são encontrados nos lugares mais distantes e mais diversos porque reproduzem os mitos, simbolizando as experiências que o ser humano passa em sua trajetória de vida. E é essa concepção de mito que permeia a obra de Joseph Campbell e serviu de base para a criação da jornada do herói a que veremos com maiores detalhes.

Com o propósito de desvelar verdades que são apresentas sob diferentes disfarces - religiosos ou mitológicos -, Joseph Campbell publicou em 1949 o livro O herói de mil Faces. Nessa importante obra, o já renomado antropólogo, opera uma análise estruturalista de mitos de diferentes culturas e prova que toda a humanidade compartilha dos mesmos medos e aspirações e baseado nisso cria o conceito de monomito. O autor ressalta que, as histórias, ao apresentar informações sobre o processo de viver a vida, alimentam o espírito humano criativo, desmistificam narrativas sagradas como instrumentos inacessíveis e convidam o leitor a perceber o humano e suas manifestações em todas as culturas. 
Toda cultura humana necessita de um modelo de conduta, um arquétipo que possa suprir muitas de nossas deficiências morais e psíquicas, e essa é a premissa principal do monomito. Esse arquétipo da humanidade seria o herói. A grande parte das narrativas humanas reproduz a mesma jornada, pois, "seja o herói ridículo ou sublime, grego ou bárbaro, gentio ou judeu, sua jornada sofre poucas variações no plano essencial". (CAMPBELL, 2007, p. 42). Essa jornada idêntica é a unidade nuclear do monomito e permite afirmar que seria possível estruturar qualquer história a partir do roteiro básico da "Jornada do Herói" - Separação, iniciação e retorno -.

Campbell concebe o herói de uma maneira muito semelhante à Jung que alega que o considera essencialmente como um arquétipo, que "nasce" para suprimir muitas de nossas deficiências psíquicas e obedece ao mesmo perfil e modelo nas mais diferentes culturas. É o precursor (arquétipo) da humanidade em geral. (JUNG, 1996). O herói personifica a perfeição humana e por isso nos fascina. O herói composto do monomito é uma personagem dotada de dons excepcionais. Sobre essa premissa, Brombert (2004, p. 22) afirma que os heróis "são constantes: eles vivem segundo um código pessoal feroz, são obstinados diante da adversidade; seu forte não é a moderação, mas sim a ousadia e mesmo a temeridade. Heróis são desafiadoramente comprometidos com honra e orgulho". Apesar da aparente perfeição, o herói é obrigado a partir para uma aventura porque "ele e/ou o mundo em que se encontra sofrem de uma deficiência simbólica". (CAMPBELL, 2007, p. 42). Nos contos de fadas, essa deficiência pode ser algo singelo, e até insignificante, como a falta de um recurso mágico ou de um objeto como certo anel de ouro. Entretanto, em algumas narrativas, a vida física e espiritual de toda a terra pode ser representada em ruínas ou a ponto de se arruinar.

A jornada do herói é composta por três etapas. Na primeira - separação ou partida - o herói está em ambiente seguro, provavelmente o seu lar, quando é convocado e precisa responder a um chamado. Geralmente, o herói recusa o chamado. Porém, um encontro com algum mentor ou um auxílio sobrenatural o convence a embarcar na aventura por locais hostis. Ao sair do horizonte conhecido, o herói é colocado em provações. Campbell (2007, p. 91) define esse encontro ao desconhecido como "A ideia de que a passagem do limiar mágico é uma passagem para uma esfera de renascimento". A primeira etapa é composta por cinco partes: 1) "O chamado da aventura", ou os indícios da vocação do herói; 2) "A recusa do chamado"; 3) "O auxílio sobrenatural"; 4) "A passagem pelo primeiro limiar"; e 5) "O ventre da baleia". 
A segunda etapa seria a Iniciação que é o estágio das provas e vitórias. Essa etapa apresenta seis divisões: 1) "O caminho de provas"; 2) "O encontro com a deusa"; 3) "A mulher como tentação"; 4) "A sintonia com o pai"; 5) "A apoteose"; e 6) "A bênção última". O herói formará alianças e combaterá inimigos, enfrentará tentações e provas difíceis até encontrar a maior das provações e invariavelmente, a vencer.

Então ocorre a última etapa, o retorno. O herói recebe uma recompensa e pode voltar ao lar. Ao voltar para a casa, o herói estará transformado e trará consigo algo abstrato ou concreto- que será de grande utilidade para seu povo. As divisões dessa etapa são: 1) "A recusa do retorno"; 2) "A fuga mágica"; 3 ) "O resgate com ajuda externa"; 4) "A passagem pelo limiar do retorno"; 5) "Senhor dos dois mundos"; e 6) "Liberdade para viver".

Para Campbell (2007) é possível "desmembrar" quase todas as histórias criadas oralmente pela humanidade e identificar nelas os passos que constituem a "Jornada". O que difere uma narrativa de outra, é a forma que o herói realiza as suas façanhas. A influência do arquétipo é tão forte que é possível identificar a jornada em muitas narrativas modernas, artificialmente criadas. Cabe também acrescentar que:

Caso um ou outro dos elementos básicos do padrão arquetípico seja omitido de um conto de fadas, um ritual, uma lenda ou um mito particular, é provável que esteja, de uma ou de outra maneira, implícito - e a própria omissão pode dizer muito sobre a história e a patologia do exemplo. (CAMPBELL, 2007, p. 42).

É interessante perceber a possibilidade de traçar um paralelo entre a jornada do herói com a obra de Propp (1976; 2001). A esfera de ação do Herói - que nos interessa para Propp compreende: a partida para realizar a procura, a reação perante as exigências do doador e o casamento. Porém, a preocupação do autor não é a de definir o que seria um herói e sim apenas apontar as funções exercidas pela personagem em uma história. Dentre as ações importantes listadas pelo autor, merecem destaque: pedido feito ao herói; início da reação do herói, seguida de sua partida; recebimento de objeto mágico; viagem entre reinos; luta entre oponentes; ferimento do herói; derrota do antagonista; retorno, perseguição e salvamento do herói; proposição e realização de missão difícil; finalmente, a vitória, a reparação do encargo original, o retorno do herói e sua aclamação. Muitas das funções proppianas possuem equivalência na jornada de Campbell (2007). 
Christopher Vogler (2006), um estudioso da obra de Campbell, publicou o livro $A$ jornada do escritor: estruturas míticas para escritores, e adaptou a jornada do herói para os enredos contemporâneos ${ }^{3}$. O objetivo de Vogler (2006) foi o de tornar a teoria de Campbell conhecida entre os escritores e roteiristas, provando que a jornada do herói seria o melhor fio condutor para qualquer história. O autor prova seu ponto de vista, citando exemplos de filmes e histórias famosas. Porém, apesar de seguir a teoria de Campbell (2007), Vogler (2006) resumiu algumas etapas, omitiu algumas passagens e sintetizou a jornada do herói em doze estágios.

Os doze estágios da jornada do herói são: 1) Mundo Comum - O cotidiano, a vida normal do herói antes da história começar; 2) O Chamado da Aventura - Um problema se apresenta ao herói, ele precisa sair de sua zona de conforto; 3) Recusa do Chamado - por alguma razão o herói teme o chamado da aventura; 4) Encontro com o mentor ou Ajuda Sobrenatural - O herói encontra um mentor, ou uma entidade mágica que o faz aceitar o chamado e treina para sua aventura. 5) Cruzamento do Primeiro limiar - A passagem do mundo conhecido para o desconhecido; 6) Provações, aliados e inimigos; 7) Aproximação - O herói se aproxima do grande conflito; 8) Provação difícil ou traumática - clímax da história, o herói precisa enfrentar o seu maior desafio e saí vencedor desse enfrentamento; 9) Recompensa - O herói enfrentou a morte e agora ganha uma recompensa (o elixir). 10) O Caminho de Volta; 11) Ressurreição do Herói - o herói está transformado após as experiências que passou; 12) Regresso com o Elixir - O herói volta para casa com o "elixir", e o usa para ajudar todos no mundo comum.

Na próxima seção, analisaremos a trajetória de um personagem do livro Guerra dos Tronos (2011) e aplicaremos os doze estágios apontados por Vogler (2006) e concomitantemente relacionaremos com a teoria de Campbell e as funções dos personagens de Propp.

\section{Ned stark e a trajetória do herói}

George R. R. Martin é, atualmente, um dos escritores mais lidos no mundo, graças ao sucesso de sua saga de livros As crônicas de Gelo e Fogo (A Song of Ice and Fire).

\footnotetext{
3 Antes da publicação do livro, Christopher Vogler escreveu o A Practical Guide to The Hero With a Thousand Faces (Um Guia Prático para o Herói de Mil Faces), conhecido como Memorando de Vogler. Nos anos 80 e 90, o memorando foi utilizado pela Disney como uma espécie de manual para seus roteiristas.
} 
Não podemos considerar esse sucesso como um evento isolado, por duas importantes razões. A primeira é o fato de Martin ser herdeiro de um legado iniciado no início do século XX, com autores como J. R. R. Tolkien, ( $O$ senhor dos Anéis) e C. S. Lewis (Crônicas de Nárnia), que tornaram a fantasia épica popular, conquistando milhões de leitores e transformando essas obras em best-sellers. As histórias fantásticas, com elementos mágicos e de encantamento operam um fascínio sobre o ser humano e esta seria a segunda razão. Como o fantástico, o imaginário e o mítico sempre tiveram na literatura um terreno fértil para proliferar, não deve causar espanto que uma a obra de Martin, tanto antes, como depois da sua adaptação televisiva, tenha conquistado milhões de leitores.

Dos livros que compõe a saga, para essa análise, nos interessa apenas o primeiro volume, A Guerra dos Tronos (2011). O livro possui uma trama complexa e intrincada e nenhum personagem pode ser considerado como protagonista da história. São muitos os personagens mencionados e os focos narrativos apresentados. A história acontece em um mundo que possui semelhança com a Europa medieval: existem suseranos e vassalos, reis e senhores, códigos de cavalaria, famílias com tradições e estirpe. Entretanto, há de se fazer uma ressalva. Apesar de ser uma série de fantasia, a magia é apenas sugerida. Existem elementos sobrenaturais presentes na obra - "zumbis", lobos gigantes, dragões e feitiçaria -, porém só no final do livro há a insinuação de que terão um papel importante nas sequências. O que move o enredo são as tramas políticas, as batalhas entre as grandes famílias, a traição e a ganância pelo poder. A história é dividida em capítulos, não numerados, intitulados com o nome do personagem que será o condutor dos acontecimentos daquela parte da história. A sua perspectiva que conduz a ação. De todos os personagens, aquele que nos parece mais produtivo para analisar a sua trajetória como herói é Eddard Stark, senhor de Winterfell.

É possível analisar a trajetória de Eddard, enquanto personagem, apenas em Guerra dos Tronos, sem ser necessário estender a análise para as outras obras da série. Porém não essa a razão determinante na escolha da personagem. Eddard foi escolhido por ser o único dos personagens com ponto de vista que correspondem ao perfil do herói clássico. Apesar de narrada em terceira pessoa, a história está sempre atrelada a um personagem e a sua visão de mundo. São oito os personagens que dão nome aos capítulos: grande parte da família Stark, Eddard Stark, Catelyn, Jon, Arya, Sansa, Bran, o anão irmão da rainha, Tyrion Lannister, e do outro lado do Mar Estreito, Daenerys. Os pontos 
de vista vão alternando-se e a história vai sendo contada de acordo com o ponto de vista do personagem-título. Destes personagens, Eddard é o único homem, bem-nascido, respeitado, admirado por seus iguais, poderoso senhor, guerreiro reconhecido. De certa maneira, a personagem sintetiza elementos dos heróis clássicos e dos heróis de romances de cavalaria. Os demais personagens, ou são mulheres - com uma posição inferior na sociedade dos sete Reinos - ou possuem características que destoam da imagem de um herói clássico, como o fato de Bran ter ficado paraplégico e de Tyrion ser um anão. Não estamos afirmando que Eddard é o único personagem que reproduz a jornada do herói. A caracterização da personagem o aproxima da imagem do herói clássico e tal fator pode fazer com que os leitores interpretem Eddard como sendo o protagonista da história.

Antes de caracterizar a personagem é necessário falar um pouco sobre a ambientação da obra. A história de A guerra dos tronos (2011) é ambientada em Westeros, um continente composto por sete reinos que estão unificados e governados por um único rei, Robert Baratheon, que conquistou a coroa após uma guerra que tirou a família Targaryen do trono. As alianças, que mantém os sete reinos unidos, são bastante frágeis e a qualquer momento podem ser rompidas e culminar em uma guerra. Um desses reinos é o Reino do Norte, governado pelos Stark de Winterfell há mais de mil anos.

Eddard Stark - também nomeado como Ned - é considerado um herói na guerra da reconquista e é um dos principais aliados do Rei Robert Baratheon. É o guardião do Norte, o governante Stark, e continua a tradição da família do Norte. Porém, apenas tornou-se o herdeiro e senhor de Winterfell após a morte de seu irmão mais velho, Brandon, assassinado pelo antigo rei Targaryen. Também teve que casar com a noiva prometida de seu irmão, Catelyn, filha dos senhores da Terra dos Rios e com ela teve cinco filhos legítimos.

O importante formalista russo Tomachevski (1976) aponta que a caracterização do herói pode ocorrer de duas maneiras: direta ou indiretamente. Será direta, quando o leitor receber a informação sobre o caráter do herói pelo narrador, pelos personagens ou por uma autodescrição. É o que ocorre como Eddard Stark em A guerra dos Tronos, pois passamos a conhecer seu caráter e suas virtudes pelos olhos de seus filhos. Bran, o filho mais novo, seus irmãos e uma comitiva de cavaleiros assistem, no início da história, o senhor de Winterfell, julgar e executar um desertor. "O pai de Bran sentava-se solenemente sobre o cavalo, com longos cabelos castanhos ondulando ao vento. [...] Tirara a cara de pai, pensou Bran, e colocara a de Lorde Stark de Winterfell”. (MARTIN, 
2011, p. 15). Em outro ponto da narrativa, Arya, a filha rebelde de nove anos observa: "o pai costumava dizer que um senhor devia comer com seus homens se esperava conserválos. Arya um dia o ouviu dizer a Robb: 'conheça os homens que o seguem e deixe que eles o conheçam. Não peça aos seus homens para morrer por um estranho"”. (MARTIN, 2011, p. 158). Por meio de seus filhos, sabemos que Ned é conhecido por seu senso de justiça e é considerado um homem honrado e bondoso. Em contrapartida, os seus desafetos interpretam sua personalidade reservada como um sinal de frieza e desdém.

Tomachevski (1976) salienta que a caracterização do herói é indireta quando o caráter parte dos atos, da conduta do herói. Por diversas vezes, Eddard exerce atos de honra e bravura. Até mesmo quando Eddard precisa decapitar o desertor, a personagem dá mostras de honra ao afirmar que "o homem que dita a sentença deve manejar a espada. Se tirar a vida de um homem, deve olhá-lo nos olhos e ouvir as suas últimas palavras. E se não conseguir fazê-lo, então talvez o homem não mereça morrer”. (MARTIN, 2011, p. 17).

Após a execução do desertor, o grupo retorna para Winterfell e no caminho descobre o cadáver de uma loba gigante. Está com a garganta perfurada pelos chifres de um veado e ao seu lado estão cinco filhotes. A primeira ordem de Lorde Stark é a de matálos, porém depois da intervenção do seu filho bastardo, Ned muda sua ordem e entrega um lobo para cada criança Stark. Essa pequena passagem da história merece ser citada, pois é recheada de simbolismos. O lobo gigante é o símbolo da casa Stark e foram encontrados exatamente seis filhotes, a mesma quantidade de filhos de Eddard. A partir desse momento, os lobos seriam criados pelos Stark, transformando-se em protetores leais. Em outro ponto da história Eddard fala a sua filha Arya: "deixa-me lhe dizer algumas coisas acerca de lobos, filha. Quando as neves caem e os ventos brancos sopram, o lobo solitário morre, mas a alcateia sobrevive. [...] No inverno, devemos proteger uns aos outros, nos manter quentes, partilhar nossas forças”. (MARTIN, 2011, p. 162).

Os momentos da execução do desertor, o encontro da loba, à chegada ao castelo mostram como Eddard vive com sua família no Norte. A caracterização do lar do herói seria o primeiro estágio da jornada, denominada por Vogler (1996) como Mundo Comum; $\mathrm{O}$ autor pontua que essa fase é importante, pois, antes de mostrar alguém fora de seu ambiente costumeiro, primeiro deve-se mostrá-lo em seu mundo comum, para traçar um contraste nítido entre esse universo ordinário e o mundo especial no qual adentrará. Vogler (1996, p. 106) afirma que “o Mundo Comum da maioria dos heróis é uma 
condição estática, mas instável. As sementes da mudança e do crescimento estão plantadas, falta só um pouquinho de uma nova energia para que germinem”.

Ao voltar para o castelo, Ned recebe duas notícias: seu amigo e mentor que ocupava o cargo de Mão do Rei, Jon Arryn faleceu e o rei e toda a família real estavam chegando ao norte para uma visita. Eddard não via o rei desde o fim da guerra em que ele ajudou Robert a derrotar o clã Targaryen e assumir o trono de ferro. Após a rebelião, Robert casou-se com Cersei Lannister e tornou-se um rei glutão, gordo e bêbado, muito diferente do amigo que Ned conheceu. Ao chegar a Winterfell, o rei revela que o objetivo da visita é convida Lorde Stark para ocupar a prestigiada posição de Mão do Rei. Para ocupar o cargo, Ned precisaria deixar sua família, deixar seu lar e adentrar em uma corte cheia de perigos e armadilhas. Podemos estabelecer que nesse momento, Eddard recebe um chamado da aventura que corresponde ao segundo estágio da jornada do herói.

Segundo Campbell (2007), o chamado da aventura é um acontecimento que coloca o possível herói em uma situação de escolha. O destino convoca o herói a tomar uma importante decisão, se permanece na segurança de seu lar, ou se aceita o desafio de aventurar-se por um mundo desconhecido. Eddard, ao receber o convite de seu rei pensa “a Mão do Rei era o segundo homem mais poderoso nos Sete Reinos. Falava com a voz do rei, comandava seus exércitos, esboçava suas leis. [...] Robert agora oferecia uma responsabilidade tão grande quanto o próprio reino. Era a última coisa que desejava". (MARTIN, 2011, p. 38).

Propp (2001, p. 24) aponta uma função muito semelhante com o chamado da aventura. O filólogo define como "é divulgada a notícia do dano ou da carência, faz-se um pedido ao herói ou lhe é dada uma ordem, mandam-no embora ou deixam-no ir". O autor considera que é nesse momento que o herói é efetivamente introduzido no conto.

Seguido a isso, o próximo passo da jornada do herói - o terceiro estágio - a recusa ao chamado. Nas palavras de Campbell (2007, p. 67) "com frequência, na vida real, e com não menos frequência, nos mitos e contos populares, encontramos o triste caso do chamado que não obtém resposta; pois sempre é possível desviar a atenção para outros interesses". É o que ocorre com Eddard, quando afirma que "meus deveres estão aqui no Norte. Não tenho nenhum desejo de ser Mão do Robert”. (MARTIN, 2011 p. 46). A personagem comum recusa o chamado, pois se encontra satisfeita com a vida cotidiana e a tranquilidade lhe é cara. Ned, que acredita que deve negar o convite, pois não quer deixar a sua terra e a sua família. Vogler (1996, p. 115) pontua essa etapa da seguinte 
maneira: "o problema do herói, agora, passa a ser como ele irá responder ao chamado. [...] Estão lhe pedindo que responda "sim" a uma grande incógnita, a uma aventura que vai ser emocionante, mas também perigosa, e que pode ameaçar sua vida".

Eddard muda de opinião após tomar conhecimento de uma carta de sua cunhada acusando a Rainha e seu irmão de terem assassinado a antiga Mão do Rei. Impulsionado pela honra e pelo senso de justiça - e também pela amizade e lealdade que tem para com seu rei - Ned aceita o cargo com a intenção de proteger Robert e o reino das mãos da inescrupulosa Rainha Cersei Lannister. Campbell (2007) aponta que chega um momento em que o herói percebe que deve deixar a tranquilidade que vive e que precisa cumprir o seu papel de salvador. Nesse instante, o herói tem contato real com os riscos e obrigações que estão por vir. Propp (2001, p. 25) denomina esse movimento como "o herói-buscador aceita ou decide, reagir".

Depois da aceitação do chamado, a jornada do herói, segundo Campbell, continua com o recebimento de uma ajuda sobrenatural. Não ocorre nada semelhante com o personagem Eddard Stark. Ao decidir ir para a corte, despede-se da mulher, dos filhos e junto com a comitiva real inicia a viagem. Ned leva consigo suas filhas, juntamente com suas lobas. Talvez, poderíamos considerar a presença dos filhotes de lobo gigante como uma presença sobrenatural, já que os animais possuem uma atmosfera mágica e protetora, vigiam e protegem todos os passos dos filhos de Eddard. Vogler (1996) aponta que a ajuda não precisa ser sobrenatural, pode ser apenas um mentor. Vladimir Propp (2001) chama esse tipo de personagem de "doador" ou "provedor", porque sua função exata é fornecer ao herói algo de que ele vai precisar na jornada. Nessa perspectiva, poderíamos considerar Catelyn, a esposa de Ned como uma mentora, já que é ela que o convence a ir para Porto Real.

Durante a viagem do Norte até a capital dos sete reinos, ocorrem pequenos incidentes com as lobas de suas filhas e o príncipe herdeiro Joffrey. É possível considerar os eventos da viagem como o primeiro limiar na jornada do herói de Eddard. Para o herói das narrativas míticas, o primeiro limiar é marcado pela passagem de um território conhecido para o desconhecido. "Além desses limites, estão as trevas, o desconhecido e o perigo, da mesma forma como, além do olhar paternal, há perigo para a criança e, além da proteção da sociedade, perigo para o membro da tribo". (CAMPBELL, 2007, p. 82). O primeiro limiar, para Campbell, possui um guardião sobrenatural, mágico, e o herói necessita passar por ele. No caso de Eddard, não existe um local específico, para a 
passagem do mundo conhecido para o desconhecido. O incidente com os lobos e Joffrey pode ser apontado como o primeiro momento em que Ned Stark se depara com a falsidade e a falta de honra. Eddard tem de sacrificar a loba da filha Sansa por ordem direta da Rainha Cersei, pois uma das lobas mordeu o real braço do mimado príncipe Joffrey. Mesmo com o choro das filhas, implorando clemência para a loba, Ned não tem alternativa. Com sua espada, executa o animal com muito pesar e ordena que o cadáver seja levado para longe, para o norte, pois “A mulher Lannister nunca terá esta pele". (MARTIN, 2011, p. 118).

Para Vogler (1996, p. 132) a Travessia do Primeiro Limiar é um ato voluntário, pelo qual o herói se compromete integralmente com a aventura. O primeiro limiar de Eddard seria esse: sair de um mundo em que a honra prevalece para adentrar em um universo em que a falsidade e os jogos de manipulação imperam. O comprometimento de Eddard é expresso quando, não tendo como contestar a ordem real de matar a loba que mordeu o príncipe, Ned assume a responsabilidade pela execução.

Após o cruzamento do limiar, se encerra o primeiro ciclo da jornada do herói e inicia o segundo com o sexto estágio, denominado testes, aliados e inimigos. Propp (2001) define várias funções que apresentariam convergência com o sexto estágio como, viagem entre reinos; O herói reage diante das ações do futuro doador; luta entre oponentes; ferimento do herói, entre outros. Para Campbell (2007, p. 95), “o herói caminha por uma paisagem onírica povoada por formas curiosamente fluidas e ambíguas, na qual deve sobreviver a uma sucessão de provas".

Eddard, quando chega à corte em Porto Real, não passeia por uma paisagem encantada, pelo contrário, está adentrando em um lugar cheio de ardis. Porém, como herói, também precisa passar e sobreviver por diversas provas. Uma vez na corte, Eddard é empossado Mão do Rei e precisa governar sempre que o rei está ausente. Mais uma vez características do personagem são citadas como a honra, a obstinação pela verdade. Aqui temos outro estágio da jornada do herói, o enfrentamento com seus inimigos. Agora como Mão do Rei, Ned inicia uma investigação sobre a Rainha e sobre o clã Lannister, procurando descobrir tudo o que houve antes da morte de John Arryn. Investigando as atividades de Jon Arryn antes de sua morte, Ned descobriu que Jon passava muito tempo na companhia de Stannis Baratheon, e havia visitado diversos bastados de Robert na cidade. Encontrar aliados também é pontado por Campbell como algo inerente à jornada do herói. Porém, Eddard não encontra aliados confiáveis em Porto Real. Mesmo assim, 
por acreditar na honra dos homens, Ned, confia em homens com uma postura muito ambígua como Lorde Baelish.

Em determinado ponto da história, o Rei Robert Baratheon convoca uma sessão do conselho real e exige que a princesa grávida Daenerys Targaryen - Filha do antigo rei que foi deposto e morto na guerra da sucessão e que está em outro continente - fosse morta. Ned, por ser contra o assassinato de inocentes se declara contra e entra em confronto direto com o rei. Sem alternativa, renuncia ao cargo de Mão.

Apesar de ter quase negado o convite de ser a Mão do Rei, ao ser deposto do cargo, Ned não fica satisfeito com a ideia de voltar para o norte, pois sente que a sua missão na corte ainda não está completa. Podemos perceber isso no seguinte trecho:

E, no entanto, a ideia de partir também o irritava. Ainda havia tanto a fazer. Robert e seu conselho de covardes e aduladores iam reduzir o Reino à miséria se ninguém os controlasse... ou, o que era pior, iam vendê-lo aos Lannister em pagamento dos seus empréstimos. E a verdade sobre a morte de Jon Arryn ainda lhe fugia. (MARTIN, 2011, p. 253).

Antes de sua partida de Porto Real para retornar a Winterfell, Ned resolve investigar pela última vez a morte de John Arryn e vai até um bordel visitar uma suposta filha bastara de Robert, uma garota chamada Barra. Retornando deste encontro, ele sofreu uma emboscada de Jaime Lannister, irmão da rainha, clamando por vingança pelo sequestro de seu irmão, Tyrion, por Catelyn ${ }^{4}$. Ned vê todos os seus homens de confiança ser brutalmente mortos e ao travar combate com Jaime Lannister tem sua perna gravemente ferida. Esse ponto da história seria o sétimo estágio da jornada do herói, a aproximação da caverna oculta, o momento que o herói se aproxima do covil do inimigo (VOGLER, 1996). No contexto da história, o covil do inimigo poderia ser a descoberta sobre as circunstâncias da morte da antiga Mão do Rei. No confronto com Jaime Lannister, Eddard é ferido gravemente na perna. Isso corresponde a duas das funções de Propp (2001), o herói e seu antagonista se defrontam em combate direto e o herói é marcado, ou seja, ferido em combate.

Acamado e sem ter como se locomover, Ned e as filhas não podem viajar para o norte. Nesse momento, Ned recebe uma visita do rei, implorando por sua permanência

\footnotetext{
${ }^{4}$ As tramas de "A guerra dos Tronos" ocorrem de forma concomitante. Enquanto Ned estava em Porto Real, lidando com as exigências do seu cargo, outros personagens vão tendo histórias paralelas se desenvolvendo, como é o caso de Catelyn, esposa de Ned.
} 
em Porto Real para continuar a ser Mão do Rei. Eddard vacila, mas resolve continuar no cargo. Nesse ponto da narrativa, há a preparação para o oitavo estágio da jornada, chamada por Campbell (2007) de apoteose e por Vogler (1996) como provação suprema, que seria o maior desafio e enfrentamento do herói com o seu antagonista.

Manco, Eddard continua suas investigações com ainda mais afinco e consegue descobrir que os três filhos legítimos de Robert eram, na verdade, produtos de incesto entre a Rainha Cersei Lannister e seu irmão, Jaime Lannister e provavelmente, ao descobrir a informação, a antiga Mão do Rei ao descobrir, foi assassinado. A Mão do Rei acredita que foi a rainha e seu irmão que derrubaram o seu filho Bran do alto de uma torre, em Winterfell, quando o menino os surpreendeu.

Eddard, nesse momento, poderia ir direto ao Rei e contar o que havia descoberto. Mas, impulsionado por sua honra, resolve confrontar a própria rainha Cersei com esta informação. Neste ponto, podemos considerar que ocorre a apoteose da trajetória de Ned como herói: ele enfrenta com bravura o seu maior inimigo. A Mão do Rei dá à rainha a chance de fugir com suas crianças enquanto podia, antes de Robert retornar da caçada. Confrontada, Cersei responde "honra - ela cuspiu - Como se atreve a fazer comigo o jogo do senhor honrado? Por quem me toma? Também você tem um bastardo, eu o vi. Sempre quis saber quem era a mãe. [...] Diga-me, meu honrado Lorde Eddard, em que medida é diferente de Robert, de mim ou de Jaime?". (MARTIN, 2011, p. 346). O que o herói não considerou é que Cersei poderia usar esse tempo para orquestrar o assassinato de Robert e comprar a Patrulha da Cidade.

Podemos considerar o enfrentamento de Eddard e Cersei como o início do oitavo estágio da jornada do herói, denominado apoteose. Vogler (1996, p. 157) denomina o estágio como provação, pois, “agora, o herói está [...] enfrentando o maior desafio e o mais temível adversário. Este, sim, é o âmago da questão, o que Joseph Campbell chamou de Provação. É a mola mestra da forma heroica, a chave de seu poder mágico”. Campbell utiliza o termo apoteose nesse estágio, porque esse seria o seria o momento que o herói teria contato com seu lado divino, e assim conseguiria forças para superar os obstáculos e inimigos e voltar vitorioso.

Enquanto Eddard enfrentava a Rainha, o rei estava em uma caçada. Robert é gravemente ferido por um javali - sendo que na verdade, foi envenenado por Cersei. Com o rei em seu leito de morte, Ned recebe propostas de diversos lordes e aspirantes ao trono de dar um golpe, prender a rainha e os filhos e usurpar o poder. Eddard é incorruptível, 
não concorda e não apoia nenhum dos nobres. Então, após escrever uma carta em que declara que Eddard deve ser o regente do trono, o Rei Robert acaba falecendo.

Após o falecimento do rei, Eddard acredita que o único caminho possível é declarar o irmão mais velho de Robert como rei. Então, a Mão do Rei exige a prisão da rainha Cersei e seus filhos. O que Eddard não contava é com a traição de falsos amigos como lorde Baelish. A patrulha da cidade não cumpre as ordens de Eddard e sob as ordens de Cersei Lannister, assassina a todos os nortenhos da guarda de Ned, prende suas filhas e aprisiona Eddard na fortaleza vermelha.

Assim, Eddard, não conclui a jornada do herói, não obtém sucesso após a apoteose, caí em desgraça e coloca toda sua família e amigos em risco. Preso e condenado na fortaleza, Ned, tenta entender o que fez de errado.

O rosto de Cersei pareceu flutuar à sua frente na escuridão. Tinha os cabelos cheios de sol, mas havia troça no sorriso. 'Quando se joga o jogo dos tronos, ganha-se ou morre', sussurrou. Ned jogara e perdera, e seus homens tinham pagado o preço da sua loucura com o sangue de suas vidas. Quando pensou em suas filhas, teria chorado de bom grado, mas as lágrimas não vinham. Mesmo agora, era um Stark de Winterfell, e a dor e a raiva congelavam dentro dele". (MARTIN, 2011 p. 443).

O rei menino, Joffrey Baratheon, filho do falecido rei e de Cersei convoca o povo para o Grande septo, onde Eddard vai confessar seus crimes e ser perdoado. Arya, a filha mais nova de Eddard, consegue escapar dos guardas da rainha e vestida de moleque de rua consegue ficar invisível no meio da multidão. Pelos seus olhos o julgamento de Ned Stark nos é apresentado. Ned fez uma falsa confissão pública, mas o inesperado acontece, mesmo se declarando traidor, o Rei Joffrey ordena a sua execução e Eddard Stark é decapitado pela sua própria espada, Gelo.

Depois de enfrentar a morte e sobreviver magicamente a ela, o herói, na saga descrita por Campbell (2007) e Vogler (2006), renasceria para ser recompensado. Estes seriam os últimos estágios da saga - Recompensa, caminho de volta, Ressurreição e retorno com o Elixir. Propp (2001) também elenca uma série de funções que o personagem heroico exerce após vencer os seus inimigos. Porém, isso não encontra nenhuma representação na trajetória de Eddard como herói, já que a morte tem um caráter definitivo. Não existe nenhum renascimento para Eddard. Temos nesse ponto da narrativa uma ruptura com a jornada do herói. 
$\mathrm{Na}$ próxima sessão refletiremos sobre os possíveis significados para a desconstrução da imagem de herói de Eddard Stark justamente no momento que a jornada heroica parecia estar encaminhando-se para sua conclusão.

\section{CONSIDERAÇÕES FINAIS}

O presente trabalho teve como objetivo caracterizar a forma com que importantes teorias da narratologia - a saga do herói de Joseph Campbell (2007) e as funções dos personagens de Vladimir Propp $(2001 ; 1976)$ - podem ser analisadas e confrontadas com a trajetória do personagem Edward Stark na obra A Guerra dos Tronos (2011). A principal intenção era verificar o quanto o mito do herói está presente em uma história de fantasia épica do século XXI. Verificamos que Eddard Stark, reproduz em sua trajetória, a maioria das funções de um personagem heroico estabelecidas por Propp (2001), e completa dois terços da saga do herói fundamentada por Campbell (2007) e reestruturada por Vogler (2006). Entretanto, Eddard não completa a jornada, a personagem não tem sucesso no enfrentamento dos seus desafios e morre subitamente.

Em um primeiro contato com o livro A guerra dos Tronos, o leitor mais distraído poderia imaginar que Eddard Stark, por ter em si todas as características do herói clássico, seria o grande protagonista da obra e, como todo herói, conquistaria a vitória em seu desafio final e venceria os seus inimigos. É o próprio arquétipo do herói nos faz crer que em nenhum momento haverá outro caminho possível a não ser o triunfo do bem. Sabíamos, desde o início da leitura, que o herói teria um desafio e que o enfrentaria e sabemos disso, pois temos interiorizado o percurso, a saga do herói. Portanto, a morte de um personagem com tais características pode surpreender os leitores menos experientes.

A questão fundamental que apontamos neste trabalho, não é o fato de que, George R. R. Martin, provavelmente, possa ter se apropriado da saga do herói com o intuito de surpreender o leitor ao fazer com que herói falhe em sua missão. O que suscita reflexões são os significados possíveis que a morte de um herói-protagonista alcança no contexto de em uma obra de fantasia. E não é apenas a derrota de um herói por um inimigo mais poderoso ou o falecimento do herói motivado por algum sacrifício altruísta. Eddard morreu por ser justo, honrado e honesto, foi morto por confiar. Foi vítima do fato de ser um herói. Podemos verificar isso no último capítulo de A guerra dos tronos (2011) que tem Ned como ponto de vista. Um dos conselheiros da Rainha, Varys, visita Eddard nas 
masmorras da Fortaleza Vermelha, e o aconselha a confessar a traição. Assim, sua vida seria poupada. Ned inicialmente recusa, mas concorda em engolir sua honra para salvar a vida de sua filha Sansa que se encontrava sob custódia dos Lannister. Varys observa que "é um homem honesto e honroso, Lorde Eddard. Por vezes me esqueço disso. Conheci tão poucos ao longo da vida - lançou uma olhadela pela cela - quando vejo o que a honestidade e a honra lhe trouxeram, compreendo por que" (MARTIN, 2011, p. 447).

O herói da jornada de Campbell (2007) - e também o herói das narrativas orais russas analisados por Propp - provavelmente habita um mundo marcado pelo maniqueísmo, em que o herói representa o bem e a justiça e precisa enfrentar um perigo ou inimigo conhecido, na maioria das vezes, maligno. Eddard, apesar de também, representar o bem e a justiça, não está em um mundo dividido entre o bem e o mal, entre luz e trevas. Está em um mundo cinza, constituído pela ambiguidade, em que ações de mocinho e vilão são encontradas em um mesmo personagem. Apesar de estar em um mundo cinza, Eddard age como um herói maniqueísta. Ele sabia que a Rainha Cersei não era de confiança, e teve a oportunidade de afastá-la do poder quando descobriu seu segredo. Regido pela misericórdia, ele a poupa e espera pelas circunstâncias.

Ned morre duas vezes. "Morre" pela primeira vez ao sacrificar sua dignidade, se declarando culpado das acusações de traição e reconhecendo Joffrey como o Rei legítimo. A personagem ao fazer isso, vai contra os seus princípios. Porém precisa declarar-se culpado para proteger suas amadas filhas. Eddard percebe que colocou toda sua família em risco devido aos seus desastrosos atos e decisões. Foi justo com quem não conhece a justiça, confiou em quem não devia. Mesmo sem esperança, a Mão do Rei, deposto do seu cargo, é incapaz de chorar, pois "a dor e a raiva congelavam dentro dele". (MARTIN, 2011, p. 443).

Quando está no septo de Baelor, diante do Rei, da sua mãe Rainha Cersei e de todo o povo, para confessar sua traição, Eddard já não é o mesmo de antes, seguro de sua identidade, ele já está um pouco morto, diminuído. Tanto que seu personagem não tem voz nesse momento da história, não temos acesso aos seus pensamentos, é pelos olhos de sua filha Arya, - que está na multidão - que o leitor toma conhecimento da cena.

Poderíamos concluir que no mundo criado por Martin (2011), a honra, a honestidade e a nobreza, que são inerentes ao arquétipo do herói, não tem espaço e apenas conduzem a uma morte certa. Apesar de ser uma conclusão possível, seria precipitada, 
levando em conta que Eddard Stark não é o único herói da história, tampouco o único protagonista.

Eddard morre, mas a história não termina com ele. Seus filhos, sua viúva e os demais personagens continuam intrincados em uma história cheia de encadeamentos. Há outros personagens que reproduzem outros arquétipos, outras sagas, fazendo com que $A s$ Crônicas de Gelo e Fogo sejam um mosaico de trajetórias heroicas - e anti-heroicas com diferentes desfechos. Talvez seja a imprevisibilidade que atraia os leitores. Os caminhos conhecidos, as trajetórias já percorridas não são o suficiente para conduzir os mocinhos para o final feliz. Aliás, em um mundo como Westeros, há espaço para o final feliz? Talvez descobrir a resposta dessa pergunta seja o que motiva milhões de leitores pelo mundo.

Uma indagação importante que a presente análise suscita é em relação ao perfil de herói que a ficção de George R. R. Martin propõe. A grande maioria das obras de fantasia reproduz a saga do herói e tem personagens que possuem características típicas do arquétipo. Podemos citar, Frodo do Senhor dos Anéis e Harry Potter. Já em A Guerra dos Tronos (2011), o personagem com características de herói, não só não completa a jornada, como sofre uma desconstrução. As personagens que dão prosseguimento a história não têm os perfis que se esperam de heróis. Um deles, Tyrion, é um anão, irmão da Rainha, debochado, irônico, menosprezado pela família e pela sociedade. Outro personagem que podemos citar é John Snow, que por ser bastardo é desprezado por todos e mandando para longe, para a muralha, único lugar que um malnascido poderia ser aceito. Ou Daenerys, a herdeira Targaryen que passou toda vida sendo subjugada por seu irmão, por ser mulher e é casada contra sua vontade com um violento senhor dos cavalos. Todos as personagens citadas se encontram à margem da sociedade criada por Martin (2011) e precisam provar suas capacidades, precisam enfrentar preconceitos e romper barreiras. Representam sujeitos que estariam marginalizados na nossa sociedade também.

Eddard Stark pode não ter completado sua jornada porque o perfil de herói épico, encarnado por ele, não tem lugar na sociedade que ele está inserido. Apenas a honra e as boas intenções não são o bastante para manobrar as complexidades de um mundo traiçoeiro, em que as pessoas escondem as suas reais intenções. Neste ponto, o mundo de fantasia de Martin encontra o mundo real e podemos refletir: em nosso mundo, um homem honrado como Eddard Stark seria um herói? 


\section{REFERÊNCIAS}

BROMBERT, Victor. Em louvor de anti-heróis. São Paulo: Ateliê, 2004.

CAMPBELL, Joseph. O herói de mil faces. São Paulo: Pensamento, 2007.

GRIMAL, Pierre. Mitologia Grega. Porto Alegre: LP\&M, 2009.

JUNG, Carl Gustav. O homem e seus símbolos. São Paulo: Nova Fronteira, 1996.

MARTIN, George R. R. As crônicas de gelo e fogo. Tradução de Jorge Candeias. São Paulo: Leya, 2011.

PROPP, Vladimir. As transformações dos contos fantásticos. In: TOLEDO, Dionísio de Oliveira (org.). Teoria da literatura: formalistas russos. Porto Alegre: Globo, 1976.

Morfologia do Conto Maravilhoso. Forense Universitária/CopyMarket.com, 2001. Disponível em: <http://www.scribd.com/doc/6835700/Vladimir-I-Propp-ForenseUniversitaria-MORFOLOGIA-DO-CONTO-MARAVILHOSO>. Acesso em: 10 jul. 2014.

TOMACHEVSKI, B. Temática. In: TOLEDO, Dionísio de Oliveira (Org.). Teoria da literatura: formalistas russos. Porto Alegre: Globo, 1976.

VOGLER, Christopher. A jornada do escritor: estruturas míticas para escritores. Tradução de Ana Maria Machado. Rio de Janeiro: Nova Fronteira, 2006.

Recebido em: 15 abr. 2018

Aceito em: 28 mai. 2018 